\title{
Comprehensive assessment of the coupling coordination degree between urbanization and ecological environment in the Siberian and Far East Federal Districts, Russia from 2005 to 2017
}

\author{
Ji Zheng ${ }^{1,2}$, Yingjie Hu ${ }^{3}$, Tamir Boldanov ${ }^{1,2}$, Tcogto Bazarzhapov ${ }^{1,2}$, Dan Meng ${ }^{1,2}$, Yu Li ${ }^{\text {Corresp., } 1,2}$, Suocheng Dong \\ Corresp. 1,2 \\ 1 Institute of Geographic Sciences and Natural Resources Research, Chinese Academy of Sciences, Beijing, China \\ 2 University of Chinese Academy of Sciences, Beijing, China \\ 3 College of City Construction, Jiangxi Normal University, Nanchang, China \\ Corresponding Authors: Yu Li, Suocheng Dong \\ Email address: liy@igsnrr.ac.cn, dongsc@igsnrr.ac.cn
}

The urbanization growth in the 20th and 21st centuries has led to a series of unprecedented problems in the ecological environment. Based on constructing an integrated urbanization-ecological environment index system, this paper conducts a comprehensive evaluation of the coupling coordination degree between urbanization and the ecological environment and uncovers its spatiotemporal variation characteristics in the Siberian and Far East Federal Districts, Russia from 2005 to 2017. The coupling coordination of urbanization and the ecological environment in the Siberian and Far East Federal Districts improve from slightly unbalanced development stage to barely balanced development stage from 2005 to 2017. In 2017, more than half regions achieved the barely balanced development of urbanization and the ecological environment. However, the most desirable development stage, the superior balanced development stage, is never achieved in the Siberian and Far East Federal Districts during the study period. The spatial pattern of the coupling coordination degree of urbanization and the ecological environment in the Siberian and Far East Federal District gradually changes from "dumbbell" to "high-north low-south". The south part of the Siberian and Far East Federal Districts should be paid more attention in the future urban development process. This research will provide support in the future coordination of urban development in the Siberian and Far East Federal Districts. 


\section{Comprehensive assessment of the coupling}

2 coordination degree between urbanization and

3 ecological environment in the Siberian and Far East

4 Federal Districts, Russia from 2005 to 2017

5

6

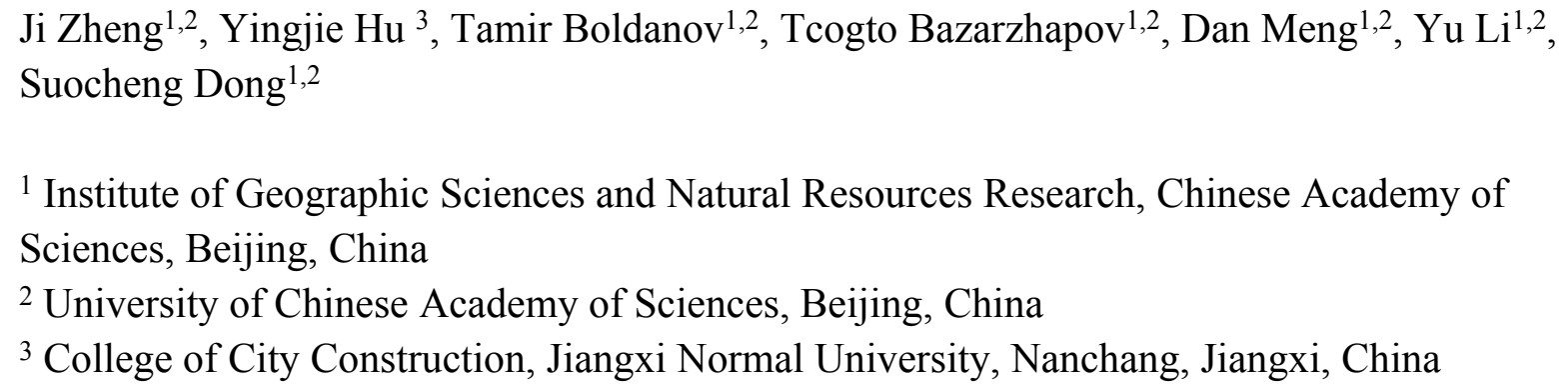

\section{Abstract}

The urbanization growth in the 20th and 21st centuries has led to a series of unprecedented problems in the ecological environment. Based on constructing an integrated urbanizationecological environment index system, this paper conducts a comprehensive evaluation of the coupling coordination degree between urbanization and the ecological environment and uncovers its spatiotemporal variation characteristics in the Siberian and Far East Federal Districts, Russia from 2005 to 2017. The coupling coordination of urbanization and the ecological environment in the Siberian and Far East Federal Districts improve from slightly unbalanced development stage to barely balanced development stage from 2005 to 2017. In 2017, more than half regions achieved the barely balanced development of urbanization and the ecological environment. However, the most desirable development stage, the superior balanced development stage, is never achieved in the Siberian and Far East Federal Districts during the study period. The spatial pattern of the coupling coordination degree of urbanization and the ecological environment in the Siberian and Far East Federal District gradually changes from "dumbbell" to "high-north lowsouth". The south part of the Siberian and Far East Federal Districts should be paid more attention in the future urban development process. This research will provide support in the future coordination of urban development in the Siberian and Far East Federal Districts. 


\section{Introduction}

38 Urbanization is a process that comprehensively shifts from rural to urban, transforming their

39

40

41

42

43

44

45

46

47

48

49

50

51

52

53

54

55

56

57

58

59

60

61

62

63

64

65

66

67

68

69

70

71

72

73

74

75

76 population, land, economies, and social properties (Bekhet \& Othman, 2017). Since 2008, the proportion of the global population living in urban areas is over 50\% (United Nations, 2019). During the 20th and 21st centuries, urbanization in developing countries has occurred at unprecedented rates. While producing enormous benefits in employment, infrastructure, service, welfare and innovation (Ochoa et al., 2018), urbanization has also caused a series of ecological and environmental problems (Zhang, 2015), including PM2.5-dominated air pollution (Fang et al., 2015; Du et al., 2019), water pollution (Ma et al., 2016), climate change (Gurney et al., 2015) and health challenges (Gong et al., 2012). Therefore, to achieve sustainable urban development, it is necessary to explore the relationship between urbanization and the ecological environment.

Many studies have provided important insights on the relationship between urbanization and the ecological environment. There are various methods being applied to investigate the relationship between urbanization and the ecological environment: STIRPAT (Stochastic Impacts by Regression on Population, Affluence and Technology) model (Lin et al., 2017), Kaya Identity (Zhang et al., 2017), LMDI (Logarithmic Mean Divisia Index) method (Ding and Li, 2017), OLS (Ordinary Least Square) method (Yu et al., 2018), GWR (Geographically Weighted Regression) model (Liang et al., 2019), panel data regression (Yao et al, 2018; Du \& Xia, 2018), Grey Correlation Analysis (Zhang et al., 2017), EKC (Environment Kuznets Curve) approach (Xu et al., 2018), Granger Causality Test (Bekhet \& Othman, 2017; Ahmed et al., 2019) and CCDM (Coupling Coordination Degree Method) (Song et al., 2018; Geng et al., 2020). However, the STIRPAT model, Kaya Identity, LMDI method, OLS method, GWR model, and panel data regression can only reveal the unidirectional influences of urbanization on the ecological environment. Grey Correlation Analysis, EKC approach, Granger Causality Test and CCDM can enrich the understanding of the bidirectional relationship between urbanization and the ecological environment. The Grey Correlation Analysis can reveal the synchronization degree of the variation of urbanization and the ecological environment and does not require a large-size sample. The EKC approach can express the relationship between urbanization and the ecological environment clearly and it is easy to use. The Granger Causality Test can reveal the influence of urbanization on the ecological environment, and it can also unravel the response of the ecological environment to urbanization. However, the Grey correlation analysis, EKC approach and Granger Causality Test can't reveal the spatiotemporal variation characteristics of the relationship between urbanization and the ecological environment. From the perspective of coordinated development, the CCDM can assess the coordination level between urbanization and the ecological environment and reveal the spatiotemporal variation characteristics of the coordination development of urbanization and the ecological environment. Fang et al. (2016) proposed that the coupling relationship between urbanization and the eco-environment will become an important international research frontier over the next 10 years. Recently, the CCDM method is widely applied to investigate the relationship between urbanization and the ecological 
77 environment (Guo et al., 2015; Liu et al., 2018; Xu et al., 2019). For example, He et al. (2017)

78

79

80

81

82

83

84

85

86

87

88

89

90

91

92

93

94

95

96

97

98

99

100

101

102

103

104

105

106

107

108

109

110

111

112

113

114

115

116

examined the relationship between urbanization and the eco-environment in Shanghai from 1980 to 2013. Yao et al. (2019) calculated the degree of coupling coordination between urbanization and ecological environments at the provincial level in 2005, 2010 and 2015 in China and observed obvious regional disparity. However, most existing research are conducted in China. Only Dong et al. (2019) conducted a quantitative assessment of the coupling coordination degree of urbanization and the eco-environment in Mongolia at the provincial level, and Zhao et al. (2017) investigated the relation of 2019 countries and regions all over the world in 2014.

Russia is an important country in the China-Mongolia-Russia Economic Corridor. To promote the national and international influences of the Siberian and Far East region, the Russian federal government proposed the Strategy of Socioeconomic Development of the Far East and the Baikal Region until 2025. In 2018, Russia and China jointly signed the China-Russia Cooperation and Development Plan in the Far East (2018-2024) to prompt the development of the Far East. The Siberian and Far East Federal Districts are expected to develop rapidly and face more challenges in their ecological environment caused by more severe anthropogenic activities over the next decade. An assessment of the coupling coordination degree of urbanization and the ecological environment in the Siberian Federal District and Far East Federal District is urgently needed. However, due to data limitations, the related research is still somewhat insufficient in this region. Chu et al. (2018) measured urbanization in the Siberian and Far East Federal Districts in Russia from the perspectives of population, economy and society, and revealed the spatial heterogeneity of urbanization development. Zhu et al. (2018) investigated the influences of urbanization and income on $\mathrm{CO}_{2}$ emissions in the BRICS (Brazil, Russia, India, China and South Africa) and observed a significantly negative influence of urbanization on $\mathrm{CO}_{2}$ emissions. Fan et al. (2018) explored the relationship between urbanization and sustainability in Asian Russia from 1990 to 2014 and found a generally positive trend of urbanization during the study period.

To rectify the above shortcomings, this paper establishes a comprehensive index system for the urbanization-ecological environment system, quantitatively evaluates the coupling coordination degree of urbanization and the ecological environment, and reveals the spatiotemporal variations of the coupling coordination degree in the Siberian and Far East Federal Districts in Russia during 2005-2017. It will provide scientific support and insights into coordinating urbanization development and ecological environment protection in the Siberian and Far East Federal Districts in Russia.

\section{Materials \& Methods}

\section{Study area and data collection}

This study conducts a comprehensive evaluation of the coupling coordination degree of urbanization and ecological environment in the Siberian Federal District and the Far East Federal District (Figure 1). The Siberian Federal District includes three republics (the Republic of Altay, Republic of Tuva, and Republic of Khakassia), five oblasts (Omsk Oblast, Novosibirsk Oblast, 
117 Tomsk Oblast, Kemerovsk Oblast and Irkutsk Oblast), and two krais (Altai Kray and 118 Krasnoyarsk Kray). The Far East Federal District includes two republics (the Republic of 119 Buryatia and Republic of Sakha), three oblasts (Amursk Oblast, Magadansk Oblast and Sakhalin 120 Oblast), two autonomous oblasts (Jewish Autonomous Oblast and Chukotska Autonomous 121 Oblast), and four krais (Khabarovskiy Kray, Primorskiy Kray, Kamchatskiy Kray and 122 Zabaykalskiy Kray). All urbanization and ecological environment data from 2005-2017 were 123 collected from the Regions of Russia Socio-Economic Indicators P32 Statistical Yearbook 124 (Russian Federal State Statistics Service, 2006-2018).

125

\section{Comprehensive urbanization-ecological environment index system}

Urbanization is an integrated development that not only reflects an increase in urban population but also an expansion of urban land, economy and lifestyle to a rural area (Weng, 2007; Bekhet \& Othman., 2019). Considering the comprehensiveness of the process of urbanization and the data limitation of spatial urbanization in the Siberian and Far East Federal Districts, three first grade indicators, including demographic urbanization, economic urbanization and social urbanization, are selected into the urbanization subsystem. Referred to the previous research, which build the urbanization index system and investigate the relation between urbanization and ecological environment (Zhao et al., 2016; He et al., 2017; Wang et al., 2020), the most cited and as comprehensive as possible basic indicators are collected. Therefore, the urbanization index subsystem consists of three primary indicators and 12 basic indicators (Table 1). According to the environmental pressure-state-response framework, widely used in the ecological environment (Hughey et al., 2004; Liu et al., 2018), we establish an ecological environment index subsystem containing three first grade indicators (ecological environment pressure, ecological environment state, and ecological environment response). Regarding the basic indicators of the ecological environment pressure and response, the solid, liquid and air pollutants are covered as much as possible. Since the crops and forests are both essential ecological and resource elements, forest area per capita and sown area of all crops per capita are selected as the basic indicators of the ecological environment state.

We employed the modified entropy method to determine the weight of each indicator in the comprehensive urbanization-ecological environment index system. The detailed steps of the entropy model are as follows:

Normalization pre-processing. All indicators were normalized by Equation (1) and (2) to remove the effects of dimension, magnitude and orientation:

Positive indicator (favorable condition):

$$
r_{i j}=\frac{x_{i j}-\min \left(x_{j}\right)}{\max \left(x_{j}\right)-\min \left(x_{j}\right)}
$$

Negative indicator (unfavorable condition): 
154

155

156

157

158

159

160

161

162

163

164

165

166

167

168

169

170

171

172

173

174

175

176

177

178

179

180

181

182

183

184

185

186

where $\mathrm{i}$ denotes the year, $\mathrm{j}$ denotes the indicator, $r_{i j}$ denotes the normalized value, $X_{i j}$ denotes the original value, $\max \left(X_{j}\right)$ denotes the maximum value of the indicator $\mathrm{j}$ during the study period, and $\min \left(X_{i j}\right)$ denotes the minimum value of the indicator $\mathrm{j}$ during the study period.

Information entropy of the indictor $\mathrm{j}\left(e_{j}\right)$ :

$$
\mathrm{e}_{j}=-\frac{1}{\ln n} \sum_{i=1}^{n} X_{i j} \times \ln X_{i j}\left(0 \leq e_{j} \leq 1\right)
$$

$$
\mathrm{X}_{i j}=\frac{r_{i j}}{\sum_{i=1}^{n} r_{i j}}
$$

where $X_{i j}$ denotes the proportion of the indicator $\mathrm{j}$ in year $\mathrm{i}, \mathrm{n}$ is the number of years (2005-2017, $\mathrm{n}=13)$.

$$
\text { Entropy redundancy }\left(g_{j}\right) \text { : }
$$

$$
\mathrm{g}_{j}=1-e_{j}
$$

Weight of the indicator $\mathrm{j}\left(w_{j}\right)$ :

where $\mathrm{m}$ denotes the number of indicators $(\mathrm{m}=11$ for the urbanization index subsystem, $\mathrm{m}=6$ for the ecological environment subsystem).

$$
w_{j}=\frac{\mathrm{g}_{j}}{\sum_{j=1}^{m} g_{j}}
$$

Comprehensive level in year i $\left(Y_{i}\right)$ :

$$
Y_{i}=\sum_{j=1}^{m} Y_{i j}
$$

The weight of each indicator in the urbanization-ecological environment index system is shown in Table 1.

\section{Coupling coordination degree model (CCDM)}

Coupling is the interactive influence between two or more systems. Urbanization may cause a series of ecological and environmental problems (Chen et al., 2006), and conversely, a deteriorated and fragile ecological environment will limit urbanization development ( $\mathrm{i} i$ et al., 2011). The modified coupling coordination degree model is as follows (He et al., 2017):

$$
C=\left\{f(U) \times g(E) /([f(U)+g(E)] / 2)^{2}\right\}^{1 / 2}
$$

where $C$ denotes the coupling degree of urbanization and ecological environment, $\mathrm{f}(\mathrm{U})$ denotes the urbanization subsystem, and $g(E)$ denotes the ecological environment subsystem.

The level of influence of urbanization and ecological environment:

$$
T=\alpha f(U)+\beta g(E)
$$

where $T$ denotes the level of influence of urbanization and ecological environment, $\alpha$ denotes the contribution of urbanization to the comprehensive system, and $\beta$ denotes the ecological 
187 environment's contribution to the comprehensive system. The value of $\alpha$ and $\beta$ are also

188

189

190

191

192

193

194

195

196

197

198

199

200

201

202

203

204

205

206

207

208

209

210

211

212

213

214

215

216

217

218

219

220

221

222

223

224

225

226

227 determined by entropy method ( $\alpha=0.467, \beta=0.533)$.

The coupling coordination degree of urbanization and ecological environment:

$$
D=\sqrt{C \times T}
$$

Table 2 shows the typology of the developmental stages of the coupling coordination degree of urbanization and the ecological environment. It can be divided into four primary stages (balanced development, transitional development, slightly unbalanced development, and seriously unbalanced development) and 12 basic stages.

\section{Results}

Each indicator's weight in the urbanization index subsystem and the ecological environment index subsystem is assessed by the entropy method separately (Table 1). The weights of the basic indicators of the urbanization index subsystem are: population density $(22.19 \%)>$ gross regional product per capita $(14.54 \%)>$ number of sports facilities per 10,000 population $(14.53 \%)>$ average income per capita $(8.88 \%)>$ per capita monetary expenses and savings $(7.15 \%)>$ the volume of communication services per capita $(6.09 \%)>$ number of high education institutions per 10,000 population $(5.99 \%)>$ number of doctors per 10,000 population $(5.62 \%)>$ percentage of economic activity population (3.62\%) > unemployment rate $(1.50 \%)$. Three basic indicators, population density, gross regional product per capita and number of sports facilities per 10,000 population, account for more than half of the total impact in relation to the comprehensive urbanization level. Our research suggests that population aggregation, economic growth and facilities improvement are all the important driving factors of the urbanization development of the Siberian and Far East Federal Districts during the past decade. This result is somewhat different from existing research. He et al. (2017) and Liu et al. (2018) found that percentage of urban population, per capita GDP and economic structure have great influence on the comprehensive urbanization in China in the recent decades. Dong et al. (2019) found that population density and economic structure are key driving elements of the comprehensive urbanization development in Mongolia. Since the high percentage of urban population of most regions in the Siberian and Far East Federal Districts (only the urban population rate of the Republic of Altay is below 50\%, at 29\%), population density, not percentage of urban population, has great influence on the comprehensive urbanization level. There are two main reasons for the high percentage of urban population in the Siberian and Far East Federal Districts: (1) More and better work opportunities attract people to aggregate in urban areas; and (2) higher level of the infrastructure and services in the urban area. In particular, heating costs in this severely cold region are much higher in rural areas than urban areas. Our results support that for the sparsely populated and severely cold Siberian and Far East Federal Districts, policy makers should pay more attention to the population density and the construction of urban infrastructures and service facilities when formulating the urban development policies.

4 basic indicators, including forest area per capita $(29.22 \%)$, sown area of all crops per capita $(26.42 \%)$, capture of air pollutants from stationary sources per capita $(19.28 \%)$ and volume of circulating and consistency used water per capita (18.75), account for $93.67 \%$ of the 
228

229

230

231

232

233

234

235

236

237

238

239

240

241

242

243

244

245

246

247

248

249

250

251

252

253

254

255

256

257

258

259

260

261

262

263

264

265

266

267

total influences on the ecological environment. The ecological environment state and ecological environment response are the essential factors of the ecological environment subsystem. The results indicate that the intrinsic endowment heterogeneity of the ecological environment is high in the vast territory, and that existing ecological environment protection measures in the Siberian and Far East Federal Districts are effective.

\section{Spatial pattern of the comprehensive urbanization level}

The comprehensive urbanization scores of the Siberian Federal District and the Far East Federal District are obtained by averaging the comprehensive urbanization scores of each region. The comprehensive urbanization scores of the two federal districts from 2005 to 2017 are shown in Figure 2. The comprehensive urbanization scores of the Siberian Federal District and the Far East Federal District both show an increasing trend during the period of 2005-2017. The comprehensive urbanization scores of the Far East Federal District increases faster than the Siberian Federal District during the study period. The comprehensive urbanization score of the Siberian Federal District increases from 0.1787 in 2005 to 0.2902 in 2017, with average annual growth rate of $4.12 \%$. The comprehensive urbanization score of the Far East Federal District increases from 0.1650 in 2005 to 0.3541 in 2017, with average annual growth rate of $6.57 \%$. It is noteworthy that 2009 is a turning point. From 2005 to 2008, the comprehensive urbanization score of the Siberian Federal District was higher than the Far East Federal District. Since 2009, the comprehensive urbanization score of the Far East Federal District surpassed the comprehensive urbanization score of the Siberian Federal District and the gap of the comprehensive urbanization level between the Far East Federal District and the Siberian Federal District become larger continuously from 2009 to 2017. In 2009, the Outline of Cooperation Plan between Northeast Region in China and Far East and East Siberian Region in Russia was signed by the governments of China and Russia promote the cooperation between the two countries in the fields of trade, investment, infrastructure construction, energy and high technology. In 2014, the government of the Russia enacted the Federal Law of Russian Social Economic Advanced Development Region to promote the development of the Far East Federal Districts. These macroscopic policies proposed in the recent decade are important for the relatively rapid urbanization development in the Far East Federal District.

The "dumbbell" spatial pattern of the comprehensive urbanization levels in the Siberian and Far East Federal Districts during 2005-2017 is shown in Figure 3. The Siberian and Far East Federal Districts have higher comprehensive urbanization levels in the western and eastern regions, and lower comprehensive urbanization levels in the central region. In 2005, the comprehensive urbanization scores are ranked as follows: Kemerovsk Oblast (0.3446) > Novosibirsk Oblast (0.2489) $>$ Omsk Oblast (0.2334) > Chukotska Autonomous Oblast (0.2160) $>$ Khabarovskiy Kray (0.2142) > Altai Kray (0.2019) > Kamchatskiy Kray (0.1971) > Amursk Oblast $(0.1933)>$ Tomsk Oblast $(0.1808)>$ Sakhalin Oblast $(0.1800)>$ Magadansk Oblast $(0.1632)>$ Republic of Khakassia $(0.1537)>$ Primorskiy Kray $(0.1477)>$ Republic of Sakha $(0.1469)>$ Zabaykalskiy Kray $(0.1464)>$ Krasnoyarsk Kray $(0.1395)>$ Irkutsk Oblast $(0.1380)>$ Jewish Autonomous Oblast (0.1219) $>$ Republic of Buryatia $(0.0882)>$ Republic of Tuva 
$268(0.0752)>$ Republic of Altay (0.0713). The top 10 comprehensive urbanization score regions 269 consist of 5 regions in the Siberian Federal District and 5 regions in the Far East Federal District. 270 In 2017, the comprehensive urbanization scores are ranked as follows: Sakhalin Oblast (0.4863)> 271 Primorskiy Kray $(0.4777)>$ Chukotska Autonomous Oblast $(0.4469)>$ Kemerovsk Oblast $272(0.4328)>$ Magadansk Oblast $(0.4304)>$ Novosibirsk Oblast $(0.3794)>$ Omsk Oblast $(0.3720)>$ 273 Khabarovskiy Kray (0.3505) $>$ Republic of Sakha (0.3449) $>$ Amursk Oblast (0.3409) $>$ Altai 274 Kray $(0.3009)>$ Krasnoyarsk Kray $(0.2770)>$ Republic of Buryatia $(0.2679)>$ Republic of 275 Khakassia $(0.2668)>$ Tomsk Oblast $(0.2654)>$ Kamchatskiy Kray $(0.2584)>$ Irkutsk Oblast $276(0.2555)>$ Zabaykalskiy Kray $(0.2514)>$ Jewish Autonomous Oblast $(0.2395)>$ Republic of 277 Tuva $(0.1907)>$ Republic of Altay (0.1619). The top 10 comprehensive urbanization score 278 regions consist of 3 regions in the Siberian Federal District and 7 regions in the Far East Federal 279 District in 2017. From 2005 to 2017, the comprehensive urbanization level in every region of the 280 Siberian and Far East Federal Districts all kept a continuous increasing trend. However, the 281 comprehensive urbanization develop more rapidly in the Far East Federal District. During the 282 period of 2005-2017, there are 8 regions of the top 10 fastest urbanization growing regions in the 283 Far East Federal District. It suggests that the development policies for the Far East Federal 284 District proposed by the government of Russian Federation in the past decade make good 285 progress on the social and economic development of the Far East Federal District. Despite the 286 differences of the growing rate the comprehensive urbanization level between the Siberian 287 Federal District and the Far East Federal District, the spatial characteristics of the comprehensive 288 urbanization level in the Siberian and Far East Federal District keep the "dumbbell" pattern.

289

290

291

292

293

294

295

296

297

298

299

300

301

302

303

304

305

306

307

\section{Comprehensive ecological environment level}

The comprehensive ecological environment scores of the Siberian Federal District and the Far East Federal District are calculated by averaging the comprehensive ecological environment scores in the three republics, five oblasts, and two krais in the Siberian Federal District, and in the two republics, three oblasts, two autonomous oblasts, and four krais in the Far East Federal District, respectively. The temporal variation characteristics of the comprehensive ecological environment scores of the Siberian Federal District and the Far East Federal District during 2005-2017 are shown in Figure 4. The comprehensive ecological environment level of the Siberian and Far East Federal Districts are similar and keep stable between 0.2 and 0.25 during the period of 2005-2017. The stable comprehensive ecological environment level in the Siberian and Far East Federal Districts in the recent decade indicates that the environment protection measures taken by the government and public have significantly positive influences.

The comprehensive ecological environment of the Siberian and Far East Federal Districts shows a "high-north low-south" spatial pattern (Figure 5). The comprehensive ecological environment scores are relatively higher in the north region, where are high latitude and cold. The population of the high latitude and cold region in the north part of the Siberian and Far East Federal Districts are scarce. Richer per capita natural resources and weaker destruction from anthropogenic activities on the ecological environment cause the comprehensive ecological 
308

309

310

311

312

313

314

315

316

317

318

319

320

321

322

323

324

325

326

327

328

329

330

331

332

333

334

335

336

337

338

339

340

341

342

343

344

345

346

347

environment scores higher in the north region of the Siberian and Far East Federal Districts. However, the ecological environment of the high latitude and cold region is fragile. It's difficult to recover since the fragile ecological environment is destroyed. Therefore, the north region of the Siberian and Far East Federal Districts should be paid attention during the urbanization process though the north region have relatively higher comprehensive ecological environment scores.

In 2005, the comprehensive ecological environment scores are ranked as follows: Republic of Sakha (0.3999) > Krasnoyarsk Kray (0.3969) > Chukotska Autonomous Oblast (0.3799) > Kamchatskiy Kray $(0.3371)>$ Altai Kray $(0.3324)>$ Magadansk Oblast $(0.3166)>$ Omsk Oblast $(0.2772)>$ Tomsk Oblast $(0.2567)>$ Amursk Oblast $(0.2549)>$ Kemerovsk Oblast $(0.2491)>$ Khabarovskiy Kray $(0.2142)>$ Novosibirsk Oblast $(0.2064)>$ Irkutsk Oblast $(0.2014)>$ Zabaykalskiy Kray (0.1639) > Republic of Altay (0.1574) > Republic of Buryatia (0.1422) > Republic of Khakassia (0.1352) $>$ Jewish Autonomous Oblast $(0.1264)>$ Republic of Tuva $(0.1242)>$ Sakhalin Oblast $(0.1062)>$ Primorskiy Kray (0.0794). In 2017, the comprehensive ecological environment scores are ranked as follows: Republic of Sakha $(0.4175)>$ Magadansk Oblast $(0.4150)>$ Chukotska Autonomous Oblast $(0.4050)>$ Altai Kray $(0.3530)>$ Kamchatskiy Kray $(0.3483)>$ Krasnoyarsk Kray $(0.3343)>$ Omsk Oblast $(0.2998)>$ Kemerovsk Oblast $(0.2453)>$ Irkutsk Oblast $(0.2134)>$ Amursk Oblast $(0.1945)>$ Novosibirsk Oblast $(0.1942)>$ Zabaykalskiy Kray $(0.1811)>$ Jewish Autonomous Oblast $(0.1764)>$ Khabarovskiy Kray $(0.1733)>$ Primorskiy Kray $(0.1718)>$ Republic of Khakassia $(0.1653)>$ Tomsk Oblast $(0.1611)>$ Republic of Altay (0.1556) > Republic of Buryatia (0.1394) > Republic of Tuva (0.1184) > Sakhalin Oblast (0.0978). The comprehensive ecological environment scores in most regions of the Siberian and Far East Federal Districts keep stable, with the difference of the comprehensive ecological environment score between 2005 and 2017 lower than 0.03. The comprehensive ecological environment scores of 4 regions, including Khabarovskiy Kray, Amursk Oblast, Krasnoyarsk Kray and Tomsk Oblast, decrease more than 0.03 during the period of 2005-2017. The comprehensive ecological environment scores of 3 regions, including Magadansk Oblast, Primorskiy Kray and Jewish Autonomous Oblast, increase more than 0.05 during 2005 and 2017.

\section{Development stages and spatiotemporal patterns of the coupling coordination degree between urbanization and the ecological environment}

We calculated the coupling coordination degree between urbanization and the ecological environment in the Siberian Federal District and the Far East Federal District using the CCDM model on the basis of the comprehensive urbanization-ecological environment index system. According to the coupling coordination degree, the development is divided into four primary stages: superior balanced development, barely balanced development, slightly unbalanced development, and seriously unbalanced development. Each primary stage is divided into three basic stages by comparing the comprehensive urbanization score to the comprehensive ecological environment score. The coupling coordination degree between urbanization and the 
348 ecological environment of the Siberian Federal District and the Far East Federal District are 349 obtained by averaging the coupling coordination degree values of the three republics, five oblasts

350

351

352

353

354

355

356

357

358

359

360

361

362

363

364

365

366

367

368

369

370

371

372

373

374

375

376

377

378

379

380

381

382

383

384

385

386

387 and two krais in the Siberian Federal District, and the two republics, three oblasts, two autonomous oblasts and four krais in the Far East Federal District, respectively.

The coupling coordination degree of urbanization and the ecological environment in the Siberian and Far East Federal Districts during 2005-2017 is shown in Figure 6. From 2005 to 2017, the coupling coordination degree of urbanization and the ecological environment in the Siberian Federal District and the Far East Federal District both keep an increasing trend. The coupling coordination degree of urbanization and the ecological environment in the Far East Federal District increases faster than the Siberian Federal District. In the Siberian Federal District, the coupling coordination degree of urbanization and the ecological environment increases from 0.4375 in 2005 to 0.5005 in 2017, with average annual growth rate at $1.13 \%$. The Siberian Federal District achieved the coupling coordination development of urbanization and the ecological environment changing from the slightly unbalanced development stage to the barely balanced development stage in 2017. In the Far East Federal District, the coupling coordination degree of urbanization and the ecological environment increases from 0.4270 in 2005 to 0.5342 in 2017, with average annual growth rate at 1.89\%. The Far East Federal District achieved the coupling coordination development of urbanization and the ecological environment changing from the slightly unbalanced development stage to the barely balanced development stage in 2012, five years earlier than the Siberian Federal District. 2009 is a turning point. Since 2009 , the coupling coordination degree of urbanization and the ecological environment in the Far East Federal District surpasses the Siberian Federal District, and the difference of the coupling coordination degree of urbanization and the ecological environment between the Siberian Federal District and the Far East Federal District become larger.

From 2005 to 2017, the coupling coordination of urbanization and the ecological environment in the Siberian and Far East Federal Districts improved from slightly unbalanced development stage to barely balanced development stage (shown in Figure 7). Neither of superior balanced development stage and seriously unbalanced development stage exist in the Siberian and Far East Federal Districts during the study period. The number of the regions, where the coupling coordination development stage of urbanization and the ecological environment achieve barely balanced development during the period 2005-2017, increases from 4 in 2005 to 11 in 2017. In 2005, only 4 regions, including Chukotska Autonomous Oblast and Kamchatskiy Kray in the Far East Federal District, and Republic of Khakassia and Omsk Oblast in the Siberian Federal District, achieved barely balanced development. Since 2007, Republic of Sakha, Magadansk Oblast and Krasnoyarsk Kray have achieved the coupling coordination of urbanization and the ecological environment changing from slightly unbalanced development stage to barely balanced development stage. Since 2010, Primorskiy Kray and Novosibirsk Oblast have achieved the change from slightly unbalanced development stage to barely balanced development stage. Since 2015, Amursk Oblast and Khabarovskiy Kray have achieved the change from slightly unbalanced development stage to barely balanced development stage. In 
388

389

390

391

392

393

394

395

396

397

398

399

400

401

402

403

404

405

406

407

408

409

410

411

412

413

414

415

416

417

418

419

420

421

422

423

424

425

426

427

2017, more than half regions, including 4 regions in the Siberian Federal District and 7 regions in the Far East Federal District, in the Siberian and Far East Federal Districts achieved the barely balanced development of the coupling coordination of urbanization and the ecological environment.

The spatial pattern of the coupling coordination degree of urbanization and the ecological environment in the Siberian and Far East Federal Districts gradually changes from "dumbbell" pattern to "high-north low-south" pattern. At the early stage of the period 2005-2017, the coupling coordination of urbanization and the ecological environment development stages showed a "dumbbell" spatial pattern. The coupling coordination degree is higher in the east and west regions of the Siberian and Far East Federal Districts, and lower in the central region. At the late stage of the study period, the coupling coordination of urbanization and the ecological environment development stages showed a "high-north low-south" spatial pattern. Only some regions in the south part of the Siberian and Far East Federal Districts have not achieved the balanced development stage.

The coupling coordination degree results of this research are compared with the existing research in China and Mongolia during the recent decade. According to Yao et al. (2019) results, the coupling coordination degree of new urbanization and eco-environment stress achieved stable and continuous improvement from 0.389 in 2005 to 0.484 in 2016 in China. Though the stable and continuous increasing trend of the coupling coordination degree in China is similar to the Siberian and Far East Federal Districts in our research, the coupling coordination development of urbanization and the ecological environment in China, staying at the slightly unbalanced development stage and not having achieved the balanced development, is slightly worse than the Siberian and Far East Federal District in Russia Federation. The quantitative assessment of the coupling coordination degree of urbanization and the ecological environment of 22 regions in Mongolia from 2000 to 2016, conducted by Dong et al. (2019), suggests that only two regions, including Ulaanbaatar and Uvurkhangai, are at the slightly unbalanced development stage, and that other regions are all at the seriously unbalanced development in 2005. In 2016, only the capital city Ulaanbaatar achieve the barely balanced development of the coupling coordination of urbanization and the ecological environment, however, more than $80 \%$ regions are still at the seriously unbalanced development stage.

\section{Conclusions and discussion}

Based on the comprehensive assessment of the urbanization and the ecological environment, this paper conducts an evaluation of the coupling coordination degree of urbanization and the ecological environment in the Siberian and Far East Federal Districts at regional scale from 2005 to 2017. The temporal variation trend and the spatial pattern of the comprehensive urbanization level, the ecological environment status and the coupling coordination degree are revealed to provide scientific support to achieve the coordinating development of urbanization and the ecological environment in the Siberian and Far East Federal Districts. Under the background of the Belt and Road Initiative, the results are also meaningful for the green construction of the China-Mongolia-Russia Economic Corridor. 
428

429

430

431

432

433

434

435

436

437

438

439

440

441

442

443

444

445

446

447

448

449

450

451

452

453

454

455

456

457

458

459

460

461

462

463

464

465

466

From 2005 to 2017, the comprehensive urbanization level of the Siberian Federal District and the Far East Federal District both keep stable and continuous improvement. The comprehensive urbanization growing rate is higher in the Far East Federal District (6.57\%) than the Siberian Federal District (4.12\%). Since 2009, the comprehensive urbanization level of the Far East Federal District has surpassed the Siberian Federal District and the gap of the comprehensive urbanization level between the two federal districts become larger. It indicates that the policies of advanced development in the Far East Federal District have important impacts on the socio-economic development of this region. The comprehensive ecological environment level of the Siberian and Far East Federal Districts are similar and keep a relative stable level of 0.20-0.25 during the period 2005-2017.

The coupling coordination of urbanization and the ecological environment in the Siberian and Far East Federal Districts improve from slightly unbalanced development stage to barely balanced development stage from 2005 to 2017. In 2017, more than half regions, including Republic of Khakassia, Omsk Oblast, Novosibirsk Oblast and Krasnoyarsk Kray in the Siberian Federal District and Republic of Sakha, Amursk Oblast, Magadansk Oblast, Chukotska Autonomous Oblast, Khabarovskiy Kray, Primorskiy Kray and Kamchatskiy Kray in the Far East Federal District, achieve the barely balanced development of urbanization and the ecological environment. However, the most desirable development stage, the superior balanced development stage, is never achieved in the Siberian and Far East Federal Districts during the study period. More efforts should be made to achieve the superior balanced development of urbanization and the ecological environment in the study area.

The spatial pattern of the coupling coordination degree of urbanization and the ecological environment in the Siberian and Far East Federal District gradually changes from "dumbbell" to "high-north low-south". At the early stage of the period 2005-2017, the coupling coordination degree of urbanization and the ecological environment is higher in the east and west regions and lower in the central region of the Siberian and Far East Federal Districts. At the late stage, the coupling coordination degree is higher in the north regions and lower in the south regions. In 2017, only some regions in the south part of the Siberian and Far East Federal Districts have not achieved the balanced stage. The south part of the Siberian and Far East Federal Districts should be paid more attention in the future urban development process.

Since the composition differences of the integrated urbanization-ecological environment index system due to the inconsistence of the indicators related to urbanization and the ecological environment in different countries and regions, the comparability of the coupling coordination degree evaluating results among the existing research is limited. Under the background of the Belt and Road Initiative and the construction of the China-Mongolia-Russia Economic Corridor, an integrated evaluation of the coupling coordination degree of urbanization and the ecological environment along the corridor at the regional scale will be important research topics in the future. Due to the lack of spatial urbanization data, the spatial urbanization indicators are not introduced into the urbanization index subsystem in this paper. Since the ecological

Peer] reviewing PDF | (2019:11:42918:1:1:NEW 1 Apr 2020) 
467

468

469

470

471

472

473

474

475

476

477

478

479

480

481

482

483

484

485

486

487

488

489

490

491

492

493

494

495

496

497

498

499

500

501

502

503

504

environmental data are not available before 2005, this paper only evaluates the coupling coordination degree of urbanization and the ecological environment from 2005 to 2017.

\section{References}

Ahmed, Z.; Wang, Z.H.; Ali, S. 2019. Investigating the non-linear relationship between urbanization and CO2 emissions: An empirical analysis. Air Qual Atmos Hlth 12:945-953. DOI: 10.1007/s11869-019-00711-x

Bekhet, H.A.; Othman, N.S. 2017. Impact of urbanization growth on Malaysia CO2 emissions: Evidence from the dynamic relationship. J Clean Prod 154:374-388. DOI: 10.1016/j.jclepro.2017.03.174

Chen, X.; Zhao, H.; Li, P.; Yin, Z. 2006. Remote sensing image-based analysis of the relationship between urban heat island and land use/cover changes. Remote Sens Environ 104 (2): 133-146. DOI:10.1016/j.rse.2005.11.016

Chikaraishi, M.; Fujiwara, A.; Kaneko, S.; Poumanyvng, P.; Komatsu, S.; Kalugin, A. 2015. The moderating effects of urbanization on carbon dioxide emissions: A latent class modeling approach. Technologic Forecast Soc 2015 90:302-317. DOI:

10.1016/j.techfore.2013.12.025

Chu, N.C.; Zhang, P.Y.; Li, H.; Li, X. 2018. Measurement and spatial differentiation of urbanization development in the Siberian and Far East Federal Districts in Russia. Scientia Geographica Sinica 38(7):1069-1078. DOI: 10.13249/j.cnki.sgs.2018.07.008 (in Chinese) Ding, Y.; Li, F. 2017. Examining the effects of urbanization and industrialization on carbon dioxide emission: evidence from China's provincial regions. Energy 125: 533-542. DOI: 10.1016/j.energy.2017.02.156

Dong, S.C.; Zheng, J.; Li, Y.; Li, Z.H.; Li, F.J.; Jin, L.; Yang, Y.; Bilgaev, A. 2019. Quantitative analysis of the coupling coordination degree between urbanization and ecoenvironment in Mongolia. Chin Geogra Sci 29(5):861-871. DOI: 10.1007/s11769-019-1074-7

Du, W.C.; Xia, X.H. 2018. How does urbanization affect GHG emissions? A cross-country panel threshold data analysis. Appl Energ 229:872-883. DOI: 10.1016/j.apenergy.2018.08.050 Du, Y.Y.; Wan, Q.; Liu, H.M.; Liu, H.; Kaspar, K.; Peng, J. 2019. How does urbanization influence PM2.5 concentrations? Perspective of spillover effect of multi-dimensional urbanization impact. J Clean Prod 220:974-983. DOI: 10.1016/j.jclepro.2019.02.222 Fan, P.L.; Chen, J.Q.; Ouyang, Z.T.; Groisman, P.; Loboda, T.; Gutman, G.; Prishchepov, A.V.; Kvashnina, A.; Messina, J.; Moore, N.; Myint, S.W.; Qi, J.G. 2018. Urbanization and sustainability under transitional economies: A synthesis for Asian Russia. Environ Res Lett 13: 095007. DOI: 10.1088/1748-9326/aadbf8

Fang, C.L.; Liu, H.M.; Li, G.D. 2016. International progress and evaluation on interactive coupling effects between urbanization and the eco-environment. J Geogr Sci 26(8):1081-1116. DOI: $10.1007 /$ s 11442-016-1317-9 
505 Fang, C.L.; Liu, H.M.; Li, G.D.; Sun, D.Q.; Miao, Z. 2015. Estimating the impact of

506

507

508

509

510

511

512

513

514

515

516

517

518

519

520

521

522

523

524

525

526

527

528

529

530

531

532

533

534

535

536

537

538

539

540

541

542

543

urbanization on air quality in China using spatial regression models. Sustainability 7(11):1557015592. DOI: $10.3390 / \mathrm{su} 71115570$

Geng, Y.Q.; Wei, Z.J.; Zhang, H.; Maimaituerxun, M. 2020. Analysis and prediction of the coupling coordination relationship between tourism and air environment: Yangtze River Economic Zone in China as Example. Discrete Dyn Nat Soc 1406978. DOI: 10.1155/2020/1406978

Grimm, N.B.; Foster, D.; Groffman, P.; Grove, J.M.; Hopkinson, C.S.; Nadelhoffer, K.J.; Pataki, D.E.; Peters, D.P.C. 2008. The changing landscape: Ecosytem responses to urbanization and pollution across climatic and societal gradients. Front Ecol Environ 6 (5):264272. DOI: $10.1890 / 070147$

Gong, P.; Liang, S.; Carlton, E.J.; Jiang, Q.; Wu, J.; Wang, L.; Remais, J.V. 2012. Urbanisation and health in China. Lancet 379(9818):843-852. DOI: 10.1016/S01406737(11)61878-3

Gurney, K.R.; Romero-Lankao, P.; Seto, K.C.; Hutyra, L.R.; Duren, R.; Kennedy, C.; Grimm, N.B.; Ehleringer, J.R.; Marcotullio, P.; Hughes, S.; Pincetl, S.; Chester, M.V.; Runfola, D.M.; Feddema, J.J.; Sperling, J. 2015. Climate change: Track urban emissions on a human scale. Nature 525(7568):179-181. DOI: 10.1038/525179a

Guo, Y.T.; Wang, H.W., Nijkamp, P.; Xu, J.G. 2015. Space-time indicators in interdependent urban-environmental systems: A study on the Huai River Basin in China. Habitat Int 45:135-146. DOI: 10.1016/j.habitatint.2014.06.030

He, J.; Wang, S.; Liu, Y.; Ma, H.; Liu, Q. 2017. Examining the relationship between urbanization and the eco-environment using a coupling analysis: Case study of Shanghai, China. Ecol Indic 77:185-193. DOI: 10.1016/j.ecolind.2017.01.017

Hughey, K.F.D.; Cullen, R.; Kerr, G.N.; Cook, A.J. 2004. Application of the pressure-stateresponse framework to perceptions reporting of the state of New Zealand environment. $J$ Environ Manage 70 (1):85-93. DOI: 10.1016/j.jenvman.2003.09.020

Li, Y.; Li, Y.; Zhou, Y.; Shi, Y.; Zhu, X. 2012. Investigation of a coupling model of coordination between urbanization and the environment. J Environ Manage 98:127-133. DOI: 10.1016/j.jenvman.2011.12.025

Liu, N.N.; Liu, C.Z.; Xia, Y.F.; Da, B.W. 2018. Examining the coordination between urbanization and eco-environment using coupling and spatial analyses: A case study in China. Ecol Indic 93:1163-1175. DOI: 10.1016/j.ecolind.2018.06.013

Liang, L.; Wang, Z.; Li, J. 2019. The effect of urbanization on environmental pollution in rapidly developing urban agglomerations. J Clean Produc 237:117649. DOI: 10.1016/j.jclepro.2019.117649

Lin, S.; Sun, J.; Marinova, D., Zhao, D. 2017. Effects of population and land urbanization on China's environmental impact: Empirical analysis based on the extended STIRPAT model.

Sustainability 9:825. DOI: 10.3390/su9050825

Peer) reviewing PDF | (2019:11:42918:1:1:NEW 1 Apr 2020) 
544 Liu, W.J.; Jiao, F.C.; Ren, L.J.; Xu, X.G.; Wang, J.C.; Wang, X. 2018. Coupling

545

546

547

548

549

550

551

552

553

554

555

556

557

558

559

560

561

562

563

564

565

566

567

568

569

570

571

572

573

574

575

576

577

578

579

580

581

582

583

coordination relationship between urbanization and atmospheric environment security in Jinan City. J Clean Prod 204:1-11. DOI: 10.1016/j.jclepro.2018.08.244

Ma, H.L.; Chou, N.T.; Wang, L. 2016. Dynamic coupling analysis of urbanization and water resource utilization systems in China. Sustainability 8 (11):1176. DOI: 10.3390/su8111176

Ochoa, J.J.; Tan, Y.; Qian, Q.K.; Shen, L.; Mereno, E.L. 2018. Learning from best practices in sustainable urbanization. Habitat Int 78:83-95. DOI: 10.1016/j.habitatint.2018.05.013

Russian Federal State Statistics Service. 2006-2018. Regions of Russia. Socio-Economic Indicators. P32 Statistical Yearbook. Rosstat: Moscow, Russia.

Song, Q.J.; Zhou, N.; Liu, T.L.; Siehr, S.A.; Qi, Y. 2018. Investigation of a "coupling model" of coordination between low-carbon development and urbanization in China. Energ Policy 121: 346-354. DOI: 10.1016/j.enpol.2018.05.037

United Nations. 2019. 2018 Reversion of World Urbanization Prospects. Available at https://population.un.org/wup/.

Weng, Y.C. 2007. Spatiotemporal changes of landscape pattern in response to urbanization. Landscape Urban Plan 81: 341-355. DOI: 10.1016/j.landurbplan.2007.01.009

Wang, S.J.; Ma, H.T.; Zhao, Y.B. 2014. Exploring the relationship between urbanization and the eco-environment- A case study of Beijing-Tianjin-Hebei region. Ecol Indic 45:171-183.

DOI: 10.1016/j.ecolind.2014.04.006

Wang, S.J.; Gao, S.; Li, S.J. 2020. Strategizing the relation between urbanization and air pollution: Empirical evidence from global countries. J Clean Prod 243: 118615. DOI: 10.1016/j.jclepro.2019.118615

Xu, Q.; Dong, Y.X.; Yang, R. 2018. Urbanization impact on carbon emissions in the Pearl River Delta region: Kuznets curve relationships. J Clean Prod 180:614-523. DOI: 10.1016/j.jclepro.2018.01.194

Xu, D.; Hou, G.L. 2019. The spatiotemporal coupling characteristics of regional urbanization and its influencing factors: Taking the Yangtze River Delta as an example. Sustainability 11:822. DOI: $10.3390 /$ su11030822

Yao, L.; Li, X.L.; Li, Q.; Wang, J.K .2019. Temporal and spatial changes in coupling and coordinating degree of new urbanization and ecological-environmental stress in China.

Sustainability 11:1171. DOI: 10.3390/su11041171

Yao, X.L.; Kou, D.; Shao, S.; Li, X.Y.; Wang, W.X.; Zhang, C.T. 2018. Can urbanization process and carbon emission abatement be harmonious? New evidence from China. Environ Impact Asses 71:70-83. DOI: 10.1016/j.eiar.2018.04.005

Yu, Y.; Tong, Y.; Tang, W.; Yuan, Y.; Chen, Y. 2018. Identifying spatiotemporal interactions between urbanization and eco-environment in the urban agglomeration in the middle reaches of the Yangtze River, China. Sustainability 10:290. DOI: 10.3390/su10010290

Zhao, Y.B.; Wang, S.J.; Zhou, C.S. 2016. Understanding the relation between urbanization and the eco-environment in China's Yangtze River Delta using an improved EKC model and coupling analysis. Sci Total Environ 571: 862-875. DOI: 10.1016/j.scitotenv.2016.07.0667

Peer) reviewing PDF | (2019:11:42918:1:1:NEW 1 Apr 2020) 
584 Zhao, Y.B.; Wang, S.J.; Ge, Y.J.; Liu, Q.Q.; Liu, X.F. 2017. The spatial differentiation of the 585 coupling relationship between urbanization and the eco-environment in countries globally: A 586 comprehensive assessment. Ecol Model 360:313-327. DOI: 10.1016/j.ecolmodel.2017.07.009

587 Zhang, L.; Gao, S.; Wei, B.; Li, Y.; Li, H.; Wang, L.; Ye, B. 2017. Effects of urbanization on 588 rural drinking water quality in Beijing, China. Sustainability 9:461. DOI: 10.3390/su9040461

589 Zhang, X.; Zhao, Y.; Xu, X.; Wang, C. 2017. Urbanization effect on energy-related carbon 590 emissions in Jiangsu Province from the perspective of resident consumption. Pol J Environ Stud 591 26(4):1875-1884. DOI: 10.15244/pjoes/68953

592 Zhang, X.Q. 2016. The trends, promises and challenges of urbanization in the world. Habitat Int 593 54:241-252. DOI: 10.1016/j.habitatint.2015.11.018

594 Zhu, H.M.; Xia, H.; Guo, Y.W.; Peng, C. 2018. The heterogeneous effects of urbanization and 595 income inequality on CO2 emissions in BRICS economies: Evidence from panel quantile 596 regression. Environ Sci Pollut R 25:17176-17193. DOI: 10.1007/s11356-018-1900-y 
Figure 1

Administrative division of the Siberian and Far East Federal Districts

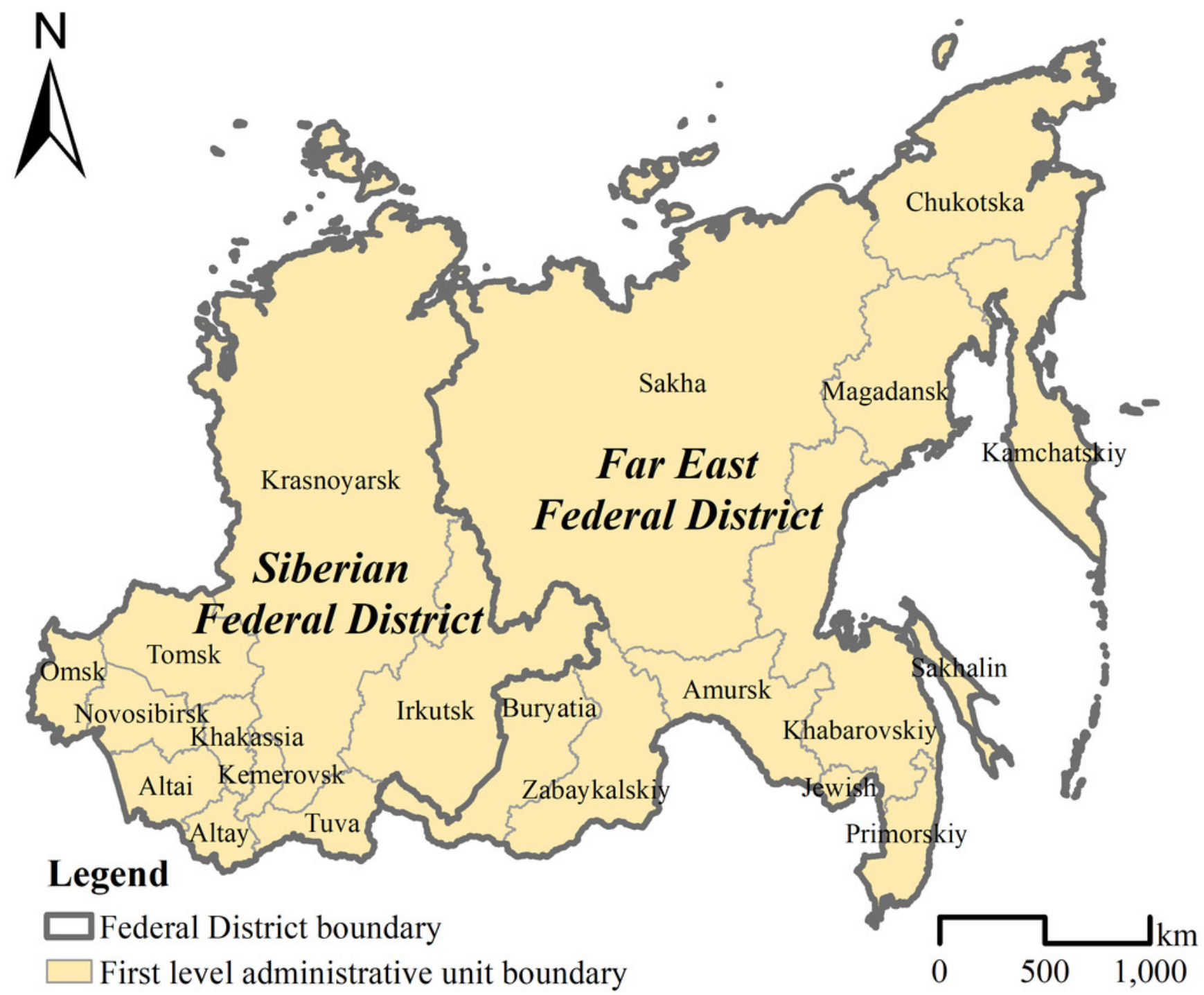


Figure 2

Cmprehensive Urbanization Scores of the Siberian and Far East Federal Districts

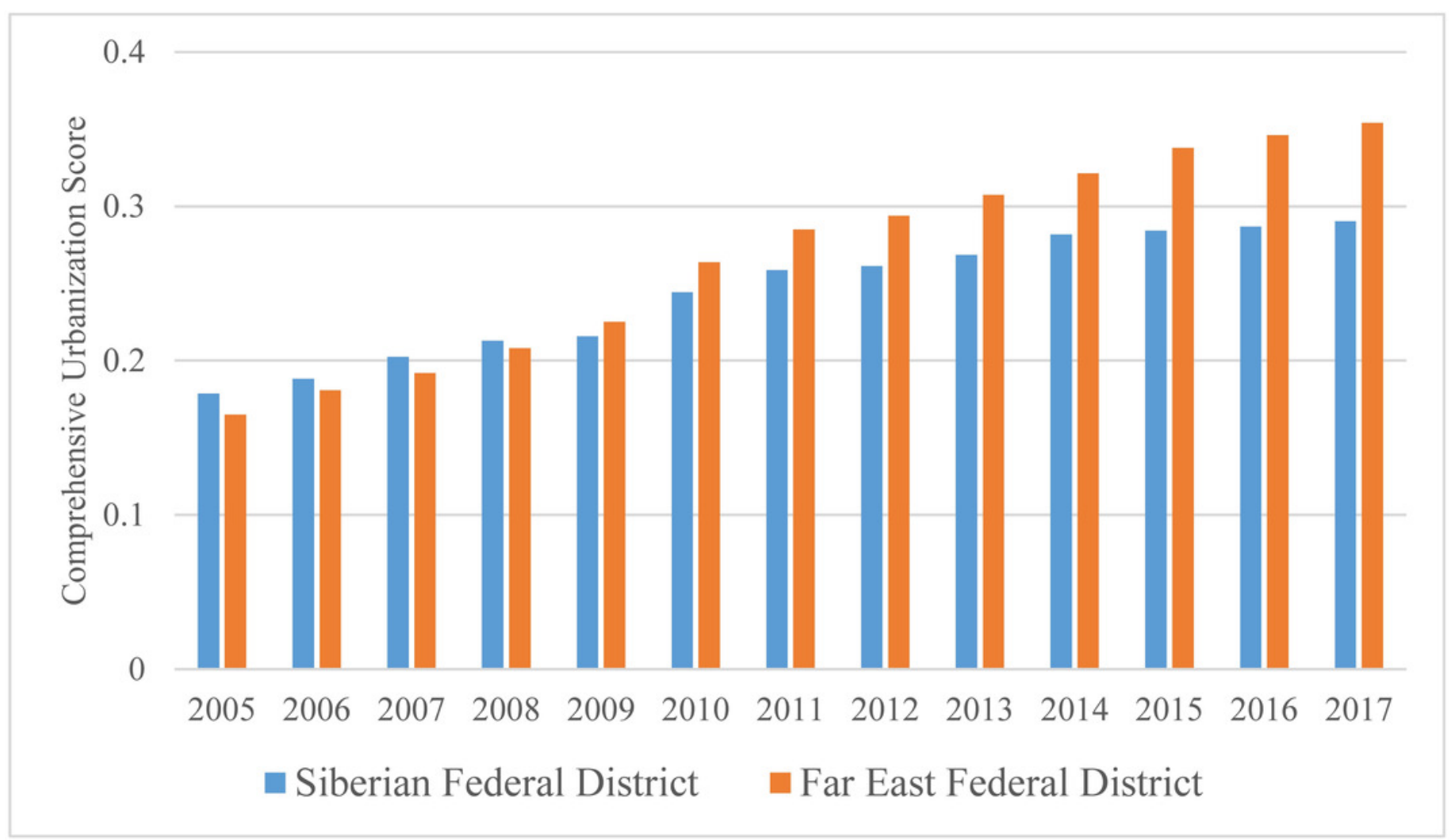


Figure 3

Spatiotemporal pattern of the comprehensive urbanization level in the Siberian and Far East Federal Districts
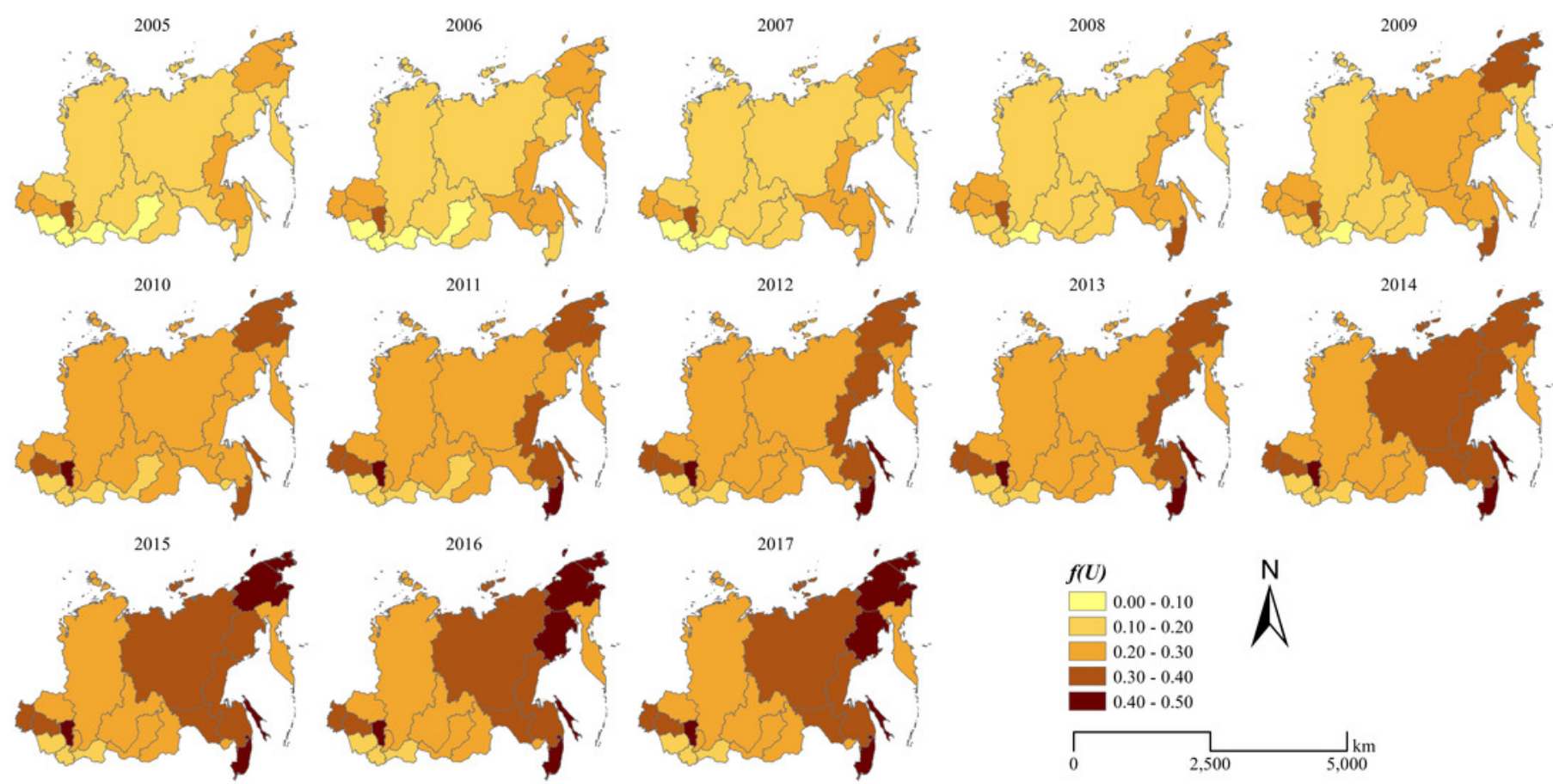
Figure 4

Comprehensive ecological environment scores of the Siberian and Far East Federal Districts

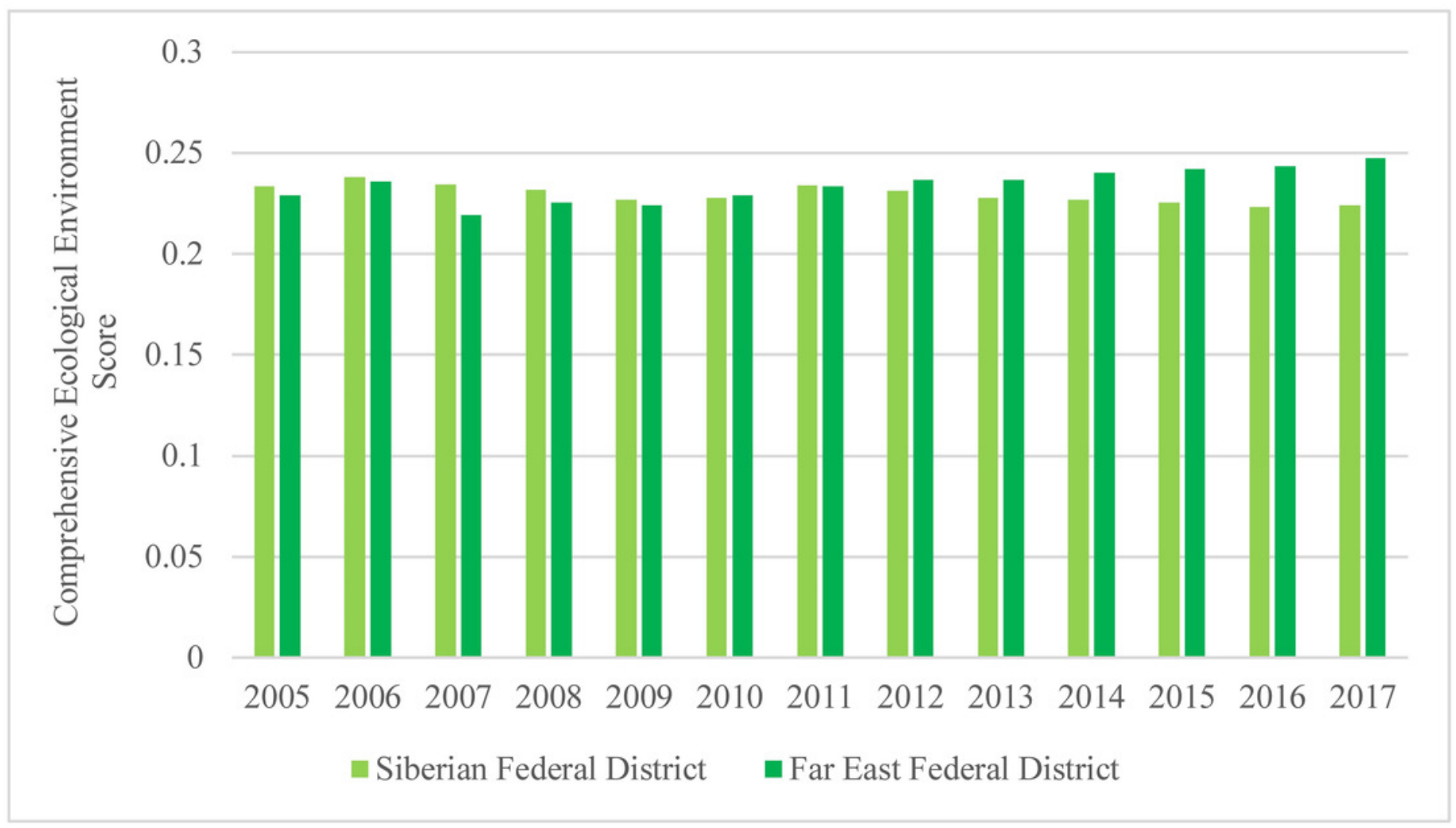




\section{Figure 5}

Spatial pattern of the comprehensive ecological environment in the Siberian and Far East Federal Districts
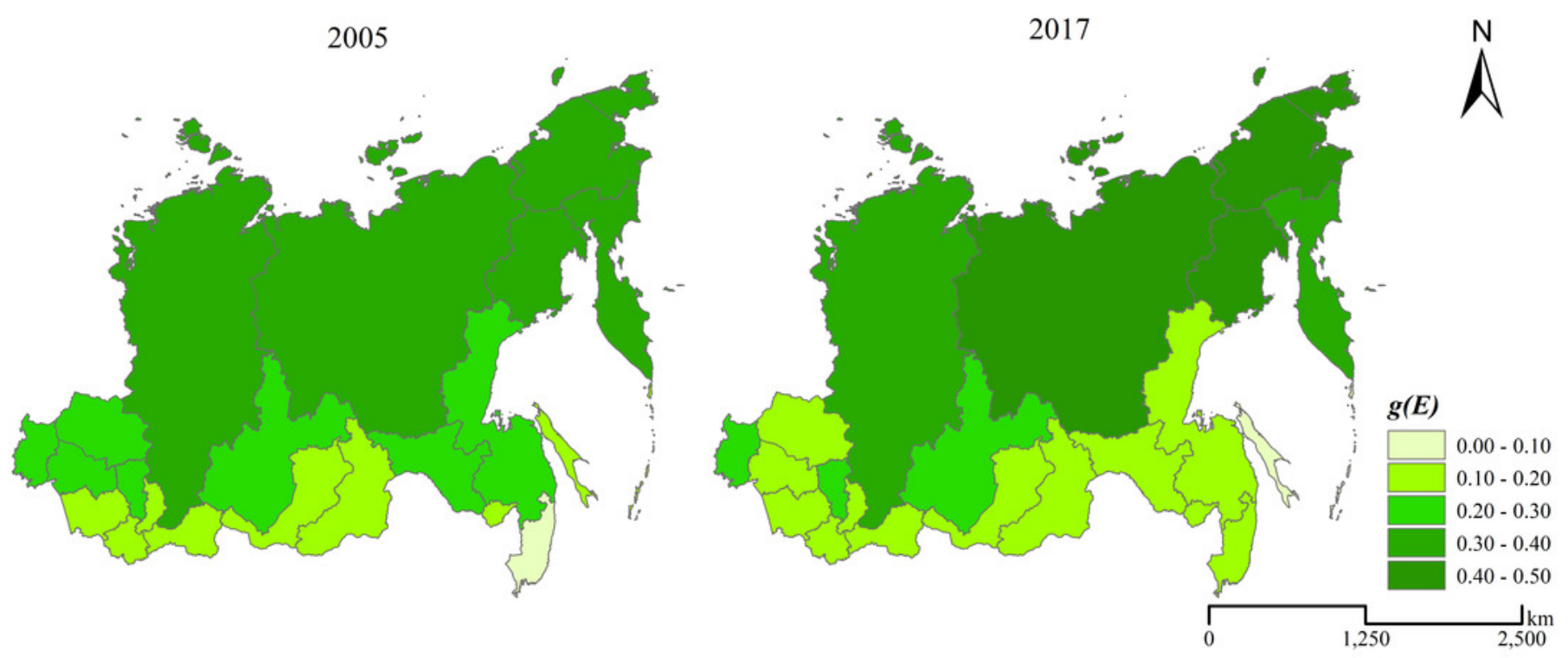
Figure 6

Temporal variation of the coupling coordination degree in the Siberian and Far East Federal Districts

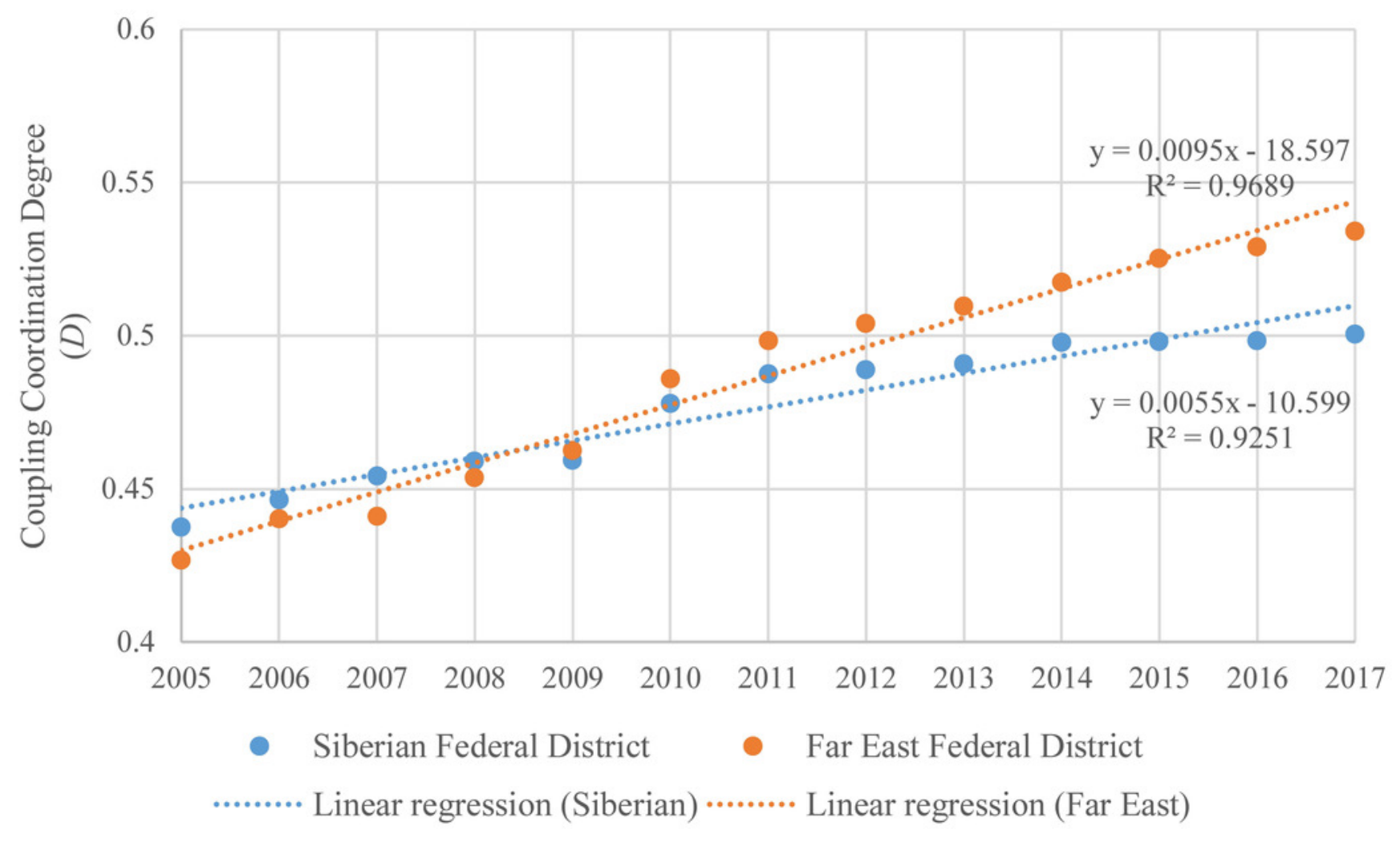




\section{Figure 7}

Spatiotemporal variation characteristics of the coupling coordination degree of urbanization and the ecological environment in the Siberian and Far East Federal Districts
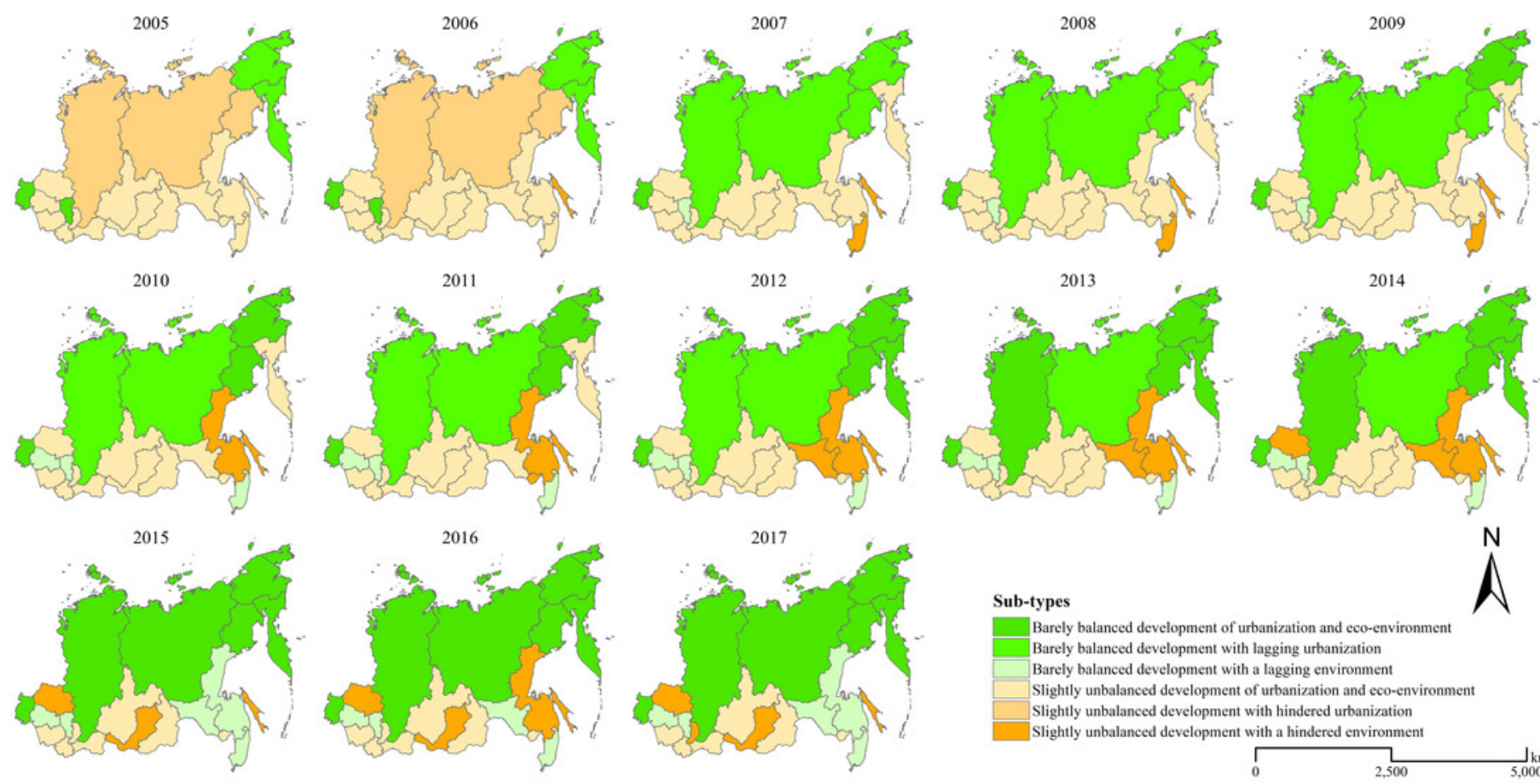

\section{Sub-types}

Barely balanced development of urbanization and eco-environment

Barely balanced development of urbanization and eco-en
Barely balanced development with lagging urbanization

Barely balanced development with a lagging environment

Slightly unbalanced development of urbanization and eco-environment

Slightly unbalanced development with hindered urbanization

Slightly unbalanced development with a hindered environment

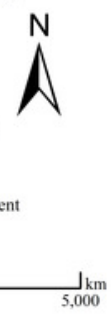


Table $\mathbf{1}$ (on next page)

Urbanization-ecological environment index system 
1 Table 1:

2 Urbanization-ecological environment index system

\begin{tabular}{|c|c|c|c|c|}
\hline Index system & $\begin{array}{l}\text { First grade } \\
\text { indicator }\end{array}$ & $\begin{array}{l}\text { Weight } \\
(\%)\end{array}$ & Basic indicator & $\begin{array}{c}\text { Weight } \\
(\%)\end{array}$ \\
\hline \multirow{12}{*}{$\begin{array}{l}\text { Urbanization } \\
\text { subsystem }\end{array}$} & \multirow{3}{*}{$\begin{array}{l}\text { Demographic } \\
\text { urbanization }\end{array}$} & \multirow{3}{*}{28.34} & Percentage of urban population $(\%)$ & 2.53 \\
\hline & & & Percentage of economic activity population (\%) & 3.62 \\
\hline & & & Population density (people/km²) & 22.19 \\
\hline & \multirow{4}{*}{$\begin{array}{l}\text { Economic } \\
\text { urbanization }\end{array}$} & \multirow{4}{*}{32.07} & Gross regional product per capita (rubles) & 14.54 \\
\hline & & & Average income per capita (rubles/month) & 8.88 \\
\hline & & & Per capita monetary expenses and savings (rubles) & 7.15 \\
\hline & & & Unemployment rate $(\%)$ & 1.50 \\
\hline & \multirow{5}{*}{$\begin{array}{l}\text { Social } \\
\text { urbanization }\end{array}$} & \multirow{5}{*}{39.59} & $\begin{array}{l}\text { Number of high education institutions per } 10,000 \\
\text { population }\end{array}$ & 5.99 \\
\hline & & & Number of doctors per 10,000 population & 5.62 \\
\hline & & & Number of sports facilities per 10,000 population & 14.53 \\
\hline & & & Number of public buses per 100,000 population & 7.36 \\
\hline & & & The volume of communication services per capita & 6.09 \\
\hline \multirow{5}{*}{$\begin{array}{l}\text { Ecological } \\
\text { environment } \\
\text { subsystem }\end{array}$} & \multirow{2}{*}{$\begin{array}{c}\text { Ecological } \\
\text { environment } \\
\text { state } \\
\end{array}$} & \multirow{2}{*}{55.64} & Forest area per capita (ha) & 29.22 \\
\hline & & & Sown area of all crops per capita (ha) & 26.42 \\
\hline & \multirow[t]{2}{*}{$\begin{array}{c}\text { Ecological } \\
\text { environment } \\
\text { pressure }\end{array}$} & \multirow[t]{2}{*}{6.33} & $\begin{array}{l}\text { Air pollutants emitted from stationary sources per capita } \\
(\mathrm{kg}) \\
\text { Polluted water discharged into surface water per capita } \\
\left(\mathrm{m}^{3}\right)\end{array}$ & 2.50 \\
\hline & & & Solid waste per capita $(\mathrm{kg})$ & 1.08 \\
\hline & $\begin{array}{l}\text { Ecological } \\
\text { environment } \\
\text { response }\end{array}$ & 38.03 & $\begin{array}{l}\text { Capture of air pollutants from stationary sources per } \\
\text { capita }(\mathrm{kg}) \\
\text { Volume of circulating and consistency used water per } \\
\text { capita }\left(\mathrm{m}^{3}\right)\end{array}$ & $\begin{array}{l}19.28 \\
18.75\end{array}$ \\
\hline
\end{tabular}

3 


\section{Table 2 (on next page)}

Typology of the development stages of the coupling coordination degree of urbanization and ecological environment 
1 Table 2:

2 Typology of the development stages of the coupling coordination degree of urbanization and ecological environment

\begin{tabular}{|c|c|c|c|}
\hline Primary stages & & & Basic stages \\
\hline \multirow{3}{*}{$\begin{array}{l}\text { Superior balanced } \\
\text { development }\end{array}$} & \multirow{3}{*}{$0.8<D \leq 1$} & $g(\mathrm{E})-f(U)>0.1$ & $\begin{array}{l}\text { Superiorly balanced development with } \\
\text { lagging urbanization }\end{array}$ \\
\hline & & $f(U)-g(E)>0.1$ & $\begin{array}{l}\text { Superiorly balanced development with } \\
\text { a lagging ecological environment }\end{array}$ \\
\hline & & $0 \leq|f(U)-g(E)| \leq 0.1$ & $\begin{array}{l}\text { Superiorly balanced development of } \\
\text { urbanization and ecological } \\
\text { environment }\end{array}$ \\
\hline \multirow{3}{*}{$\begin{array}{l}\text { Barely balanced } \\
\text { development }\end{array}$} & \multirow{3}{*}{$0.5<D \leq 0.8$} & $g(\mathrm{E})-f(U)>0.1$ & $\begin{array}{l}\text { Barely balanced development with } \\
\text { lagging urbanization }\end{array}$ \\
\hline & & $f(U)-g(E)>0.1$ & $\begin{array}{l}\text { Barely balanced development with a } \\
\text { lagging ecological environment }\end{array}$ \\
\hline & & $0 \leq|f(U)-g(E)| \leq 0.1$ & $\begin{array}{l}\text { Barely balanced development of } \\
\text { urbanization and ecological } \\
\text { environment }\end{array}$ \\
\hline \multirow{3}{*}{$\begin{array}{l}\text { Slightly unbalanced } \\
\text { development }\end{array}$} & \multirow{3}{*}{$0.3<D \leq 0.5$} & $g(\mathrm{E})-f(U)>0.1$ & $\begin{array}{l}\text { Slightly unbalanced development with } \\
\text { hindered urbanization }\end{array}$ \\
\hline & & $f(U)-g(E)>0.1$ & $\begin{array}{l}\text { Slightly unbalanced development with } \\
\text { a hindered ecological environment }\end{array}$ \\
\hline & & $0 \leq|f(U)-g(E)| \leq 0.1$ & $\begin{array}{l}\text { Slightly unbalanced development of } \\
\text { urbanization and ecological } \\
\text { environment }\end{array}$ \\
\hline \multirow{3}{*}{$\begin{array}{l}\text { Seriously unbalanced } \\
\text { development }\end{array}$} & \multirow{3}{*}{$0<D \leq 0.3$} & $g(\mathrm{E})-f(U)>0.1$ & $\begin{array}{l}\text { Seriously unbalanced development } \\
\text { with hindered urbanization }\end{array}$ \\
\hline & & $f(U)-g(E)>0.1$ & $\begin{array}{l}\text { Seriously unbalanced development } \\
\text { with a hindered ecological environment }\end{array}$ \\
\hline & & $0 \leq|f(U)-g(E)| \leq 0.1$ & $\begin{array}{l}\text { Seriously unbalanced development of } \\
\text { urbanization and ecological } \\
\text { environment }\end{array}$ \\
\hline
\end{tabular}

